\title{
Research on National Scientific Research Cooperation between China and the "One Belt and One Road"-Based on the Frontier Gravity Model
}

\author{
Wang Huan \\ Business School, Nanjing Normal University, Nanjing, China \\ Email: 457445355@qq.com
}

How to cite this paper: Huan, W. (2019) Research on National Scientific Research Cooperation between China and the "One Belt and One Road-Based on the Frontier Gravity Model. American Journal of Industrial and Business Management, 9, 1234-1253.

https://doi.org/10.4236/ajibm.2019.95083

Received: May 5, 2019

Accepted: May 24, 2019

Published: May 27, 2019

Copyright $\odot 2019$ by author(s) and Scientific Research Publishing Inc. This work is licensed under the Creative Commons Attribution International License (CC BY 4.0).

http://creativecommons.org/licenses/by/4.0/

\begin{abstract}
With the continuous development of science and technology and the deepening of international academic exchanges, international scientific research cooperation has become an important part of national strategy. Therefore, the research on the influencing factors of scientific research cooperation between China and "One Belt and One Road" countries plays an important guiding role in promoting the cultural, scientific and technological exchanges between them. This article is based on the United States patent and trademark office (USPTO) database in 2008-2017 patent cooperation data. On the basis of studying the current situation of scientific research cooperation between China and countries along the Belt and Road by means of intelligence mining, this paper innovate and quote the model of frontier gravity in economics creatively, and conducte an empirical study on the factors affecting scientific research cooperation between China and countries along the Belt and Road. The empirical results show that, except that the countries bordering on each other will inhibit China's scientific research cooperation with countries along the "One Belt and One Road", national scientific research strength, national innovation capacity, bilateral relations and economic scale will all promote the development of international scientific research cooperation. However, the geographical distance between the two countries has no significant impact on it. Besides, the limitation of this paper is that the number of patent cooperation between China and "One Belt and One Road" countries is generally small; many countries are not involved in patent cooperation, and data of some countries are missing and incomplete.
\end{abstract}

\section{Keywords}

"One Belt and One Road", International Cooperation in Scientific Research, 


\section{Introduction}

\subsection{Literature Review}

In 2013, the General Secretary of China Xi Jinping proposed the great idea of building the "Silk Road Economic Belt" and "21st Century Maritime Silk Road" (hereinafter referred to as "One Belt and One Road") after visiting central Asia and southeast Asia. In March 2015, China issued the "Vision and Action for Promoting the Construction of the Silk Road Economic Belt and the 21st Century Maritime Silk Road", pointing out that China and the countries along the "One Belt and One Road" should strengthen scientific and technological cooperation by promoting the exchange of scientific and technological personnel, working together to tackle major scientific and technological problems, and enhancing the ability of scientific and technological innovation. In recent years, with the globalization of economy, science and technology, international scientific research cooperation has become an important way which not only can promote international scientific and technological development, but also can promote cultural exchanges and scientific research and innovation. Therefore, under the background of "One Belt and One Road" strategy, it is of great significance to study and explore the current situation and influencing factors of scientific research cooperation between China and countries along the "One Belt and One Road". Because it has a great help to strengthen and promote scientific research cooperation between China and the countries along the "One Belt and One Road". At present, the researches on the topic of international scientific research cooperation mainly focus on the current situation and influencing factors of international scientific research cooperation.

Regarding the status quo of international scientific research cooperation: Michel (2010) used the probabilistic affinity to describe the cooperation between Britain, France, Germany, Japan and the United States from 1986 to 1996 [1]. And he found that the scientific research cooperation between the United States and Japan was closer than that between the other countries. Besides, from the perspective of cooperative publications, Tianwei He (2009) used bibliometrics to study the research cooperation between China and G7 countries, and found that the number of international cooperation publications increased exponentially in recent years [2]. Then, Wang and $\mathrm{Xu}$ (2013) study the international scientific research cooperation with China from the different countries, institutions and individuals [3]. The results shows that China's scientific research cooperation activities are mainly concentrated in a small number of countries, especially the United States. In recent years, more and more scholars have begun to study the status quo of scientific research within economic organizations. H. Bouabid (2016), U. Finardi (2016), and Liu Ya (2015) studied the research cooperation 
between the five BRICS countries and constructed their internal international scientific research cooperation framework [4] [5] [6]. They found that with the continuous expansion of scientific research cooperation among the BRICS countries, their scientific research dependence has gradually strengthened. Among them, a group of scholars have also conducted research on the international scientific research status of China and countries along the "One Belt and One Road". Sun Ting and Xu Changlin (2015), Wu Jiannan and Zheng Changxu (2016), Zhou Jingmei (2016), Ding Jielan (2017), Wang Jimin (2017), Bi Liangliang (2018) from the perspective of the national cooperation papers to research the status quo of paper cooperation and the citation rate of cooperative papers in countries along the route [7]-[12]. The results show that with the introduction of the "One Belt and One Road" policy, the number of international cooperation papers between China and countries along the "One Belt and One Road" has been greatly increased and China is at the core of the "One Belt and One Road" transnational papers cooperation intelligence network with the rising scientific research influence. At the same time, Ye Yangping (2016), Sun Quanliang and Wang Lei (2016), Zhang Mingqian and Deng Minmin (2018), Zhang Mingqian and Ke Li (2018) start from the perspective of China's patent cooperation, and use the intelligence analysis method to explore the characteristics of China's patent cooperation in the "One Belt and One Road" [13] [14] [15] [16]. It is found that although the national patents along the "One Belt and One Road" in China are unevenly distributed between regions and countries, the cooperation is more frequent, and the total number shows a rapid rise.

As for the influencing factors of international scientific research cooperation, existing researches mainly focus on the influence of geographical distance on scientific research cooperation. Collin (1994) and Katz (2001), through the study of the status quo of international scientific research cooperation between universities in developed countries in Europe and America, proposed a method to study the influence of geographical factors on scientific cooperation between countries [17] [18]. Their results show that face-to-face communication is more efficient than modern communication methods such as sending e-mails and conducting video conferences. Besides, research cooperation activities tend to show an exponential decline as the distance between partners increases. Adamsetal (2005) studied the relationship between geographic distance and scientific research, and found that geographic distance was positively correlated with coordination cost and negatively correlated with the intensity of cooperative research activities of researchers [19]. Hoekmanetal (2009) found that although geographical distance was negatively correlated with international scientific research cooperation, with the development of modern transportation and communication tools, the influence of geographical distance on scientific research cooperation decreased gradually, and the geographical location of team members of scientific research cooperation became more and more dispersed like a new trend [20]. At the same time, the country's own scientific and technological 
strength will also have an important impact on the research cooperation activities between countries. Wagner C S (2005) studied the current situation of scientific research cooperation between countries and found that the strength of national science and technology, the level of academic communication within the scientific community and the level of self-organization will have different degrees of influence on the scientific and technological cooperation between countries [21]. Han Tao (2013) also found that under the same conditions, a country tends to cooperate with countries with strong scientific and technological resources and strength [22]. At the same time, based on the Web of Science paper database, Zhang Cui and Ouyang dongping (2010) demonstrated through empirical research that the scientific research strength between China and countries along the "One Belt and One Road" plays a positive role in promoting the international scientific research cooperation between the two countries [23].

By sorting out the above literatures, this paper can be summarized as follows: the existing research on international scientific research cooperation between China and countries along the "One Belt and One Road" route mainly starts from the perspective of international cooperative papers and publications, and few scholars study international scientific research from the perspective of international cooperative patents. In addition, most of the current researches only focus on the current situation of scientific research cooperation based on information science knowledge, and there are few papers using the empirical analysis method of economics to study the factors affecting international scientific research cooperation. It can be seen from the above that international scientific research cooperation is an important way to enhance national innovation, increase national scientific and technological vitality, and strengthen national scientific research exchanges. Studying the influencing factors of China's scientific cooperation with the "One Belt and One Road" countries has an important guiding role in promoting China's cultural and scientific exchanges with the "One Belt and One Road" countries. Therefore, this paper will conduct an empirical analysis of the factors affecting international scientific research cooperation between China and the countries along the "One Belt and One Road" through the study of the status quo of international cooperation patents between China and the "One Belt and One Road" countries.

\subsection{Research Structure}

This paper firstly reviews and sorts out the relevant researches in the field of national scientific research cooperation, and finds that there is little analysis on the influencing factors of international scientific research cooperation in the existing research framework. Based on this, on the basis of the research on the status quo of China's patent cooperation with "One Belt and One Road", this paper puts the influencing factors of international scientific research cooperation into the research framework of international scientific research cooperation. Using the frontier gravity model of economics creatively, this paper conducts an empirical 
analysis of the influencing factors of patent cooperation between China and countries along the "One Belt and One Road" line from the perspectives of the whole and time, and finally obtains the final research conclusions and policy recommendations according to the empirical results.

This article is divided into five chapters, and the specific content is arranged as follows:

Chapter 1, introduction. It mainly introduces the background and significance of the topic, sorts out the relevant literature, explains the ideas and contents of the research, and the possible innovations of the article.

Chapter 2, analyzes the current situation of China's patent cooperation with "One Belt and One Road". The current situation of international patent cooperation is described from five aspects, including the time sequence distribution, country distribution, regional distribution, applicant and application field.

Chapter 3, model setting and sample selection. The frontier gravitational model is mainly described and the referenced variables are explained.

Chapter 4, the empirical analysis. The empirical part of this paper first determines the form of the global model by huasman test. Then carry out the overall test and the time-division test respectively, and finally carry out the significant test.

Chapter 5, conclusion and policy recommendations. Based on the empirical results in chapter 4 , this paper puts forward relevant policy suggestions.

\section{Status Analysis}

\subsection{Distribution of Cooperative Patents}

Based on the statistics of the US Patent and Trademark Office (USPTO) database, as of December 2017, China and the countries along the "One Belt and One Road" have cooperated to apply for 1217 international patents (as shown in Figure 1). As can be seen from Figure 1, from 2008 to 2017, the number of international cooperation patents of various countries increased from at least 25 to at most 218, with an increase of 8.72 times. This paper divides the "One Belt and One Road" international cooperative patent from 2008 to 2017 into three stages: 2008-2011 (initial stage of international cooperative patent); 2011-2013 (international patent cooperation is in the stage of soaring); 2013-2017 (rapid growth phase of international patents). From 2008 to 2011, the number of international patent cooperation grew slowly, and the number of international patent cooperation was unstable every year. During the period from 2011 to 2013, the number of international cooperative patents increased from 49 in 2011 to 83 in 2013. From 2013 to 2017, with the introduction of the great "One Belt and One Road" policy in 2013, the number of international patent cooperation between China and countries along the "One Belt and One Road" increased rapidly. The number of international cooperative patents climbed from 83 in 2013 to 218 in 2017. During the five-year period, a total of 756 patents were applied, accounting for $62.120 \%$ of the total number of international cooperative patents. 


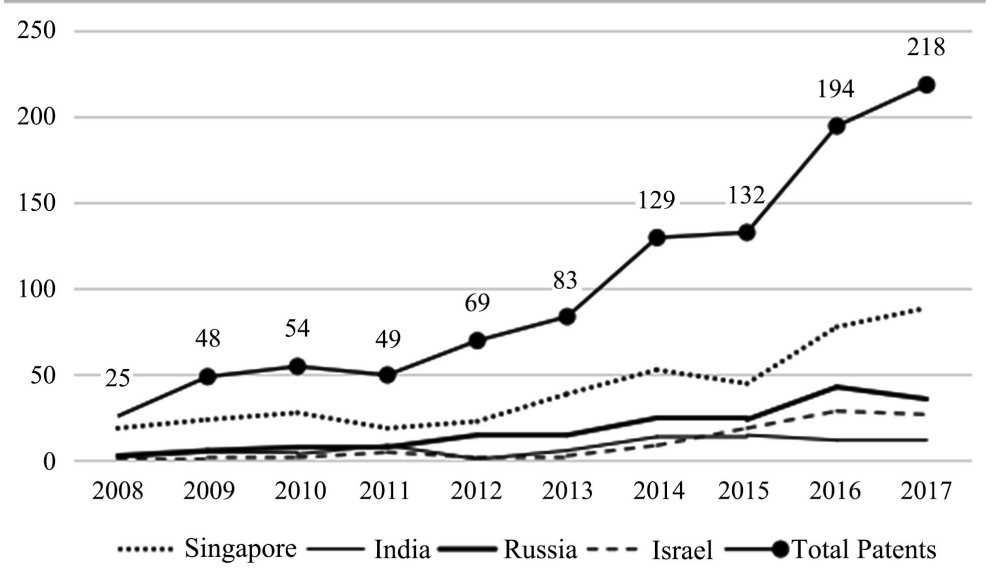

Figure 1. International cooperation patent timing distribution table.

\subsection{Distribution of Cooperative Patent Countries}

Based on the statistics of the US Patent and Trademark Office (USPTO) database, Table 1 is given. As can be seen from Table 1, as of December 2017, only 34 out of 65 countries across the board have conducted international patent cooperation with China, among which the top four countries are Singapore (539), India (181), Israel (93) and Russia (90). Moreover, the number of cooperative patents between countries along the "One Belt and One Road" and China is quite different, and the number of international cooperative patents of the top four countries accounts for $74.199 \%$ of the total number. The number of patents applied jointly by China and Singapore accounts for $44.289 \%$ of the total number, accounting for about half of the number of patents applied jointly by China and all countries along the "One Belt and One Road". India, Israel and Russia accounted for $14.873 \%, 7.642 \%$ and $7.395 \%$ of the total number of cooperative patents, respectively. In order to better analyze the trend of international patent cooperation between China and countries along the "One Belt and One Road", this paper draws a time sequence distribution diagram of the number of patents applied by China and the top four countries (Figure 1). It can be seen from Figure 1 that the change trend of the number of national patents applied by the four countries in cooperation is the same on the whole, among which the number of Singapore applications has been far ahead, all above the other three countries.

At the same time, there are 31 countries along the "One Belt and One Road" that have not applied for patents in cooperation with China. Their openness and enthusiasm of scientific research cooperation are not good, and they are marginalized. From this, we can see that the overall degree of patent cooperation between China and countries along the "One Belt and One Road" is not high, and it shows that the distribution of national patent cooperation is uneven, mainly concentrated in few countries.

\subsection{Cooperative Patent Area Distribution}

There are 65 countries along the "One Belt and One Road". However, due to the 
complexity of intellectual property rights in the region, the laws and regulations related to intellectual property rights, as well as the level of management and implementation vary. For the convenience of observation, this paperuse the viewpoint of From the viewpoint of Zhang Mingqian and Deng Minmin (2018) and divides the "One Belt and One Road" countries into six regions, namely, Mongolia and Russia, 5 countries in central Asia, 11 countries in southeast Asia, 8 countries in South Asia, 19 countries in central and eastern Europe, and 20 countries in west Asia and the Middle East, according to international practices and other factors such as geography, proximity and culture [15] (Table 2).

From the USPTO database, the study found that the regional distribution of the number of cooperative patents between China and countries along the "One Belt and One Road" is uneven: southeast Asia is the main cooperative region of China, with 706 cooperative patents, more than half of the total number. South Asia, West Asia, and the Middle East each followed 15.201\% and $11.832 \%$ of the total patents; Central and Eastern Europe, Russia and Mongolia and China have fewer cooperation patents, accounting for only $7.560 \%$ and $7.395 \%$, respectively. Besides, it is worth noting that Central Asia and China do not have cooperative patents (Figure 2).

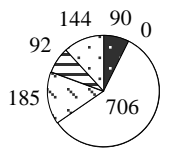

$$
\begin{array}{ll}
\square \text { North Asia } & \square \text { Central Asia } \\
\square \text { Southeast Asian } & \text { @outh Asia } \\
\square \text { Central and Eastern European } & \square \text { West Asia, the Middle East }
\end{array}
$$

\begin{tabular}{|c|c|c|c|c|c|}
\hline Nation & Patent & Nation & Patent & Nation & Patent \\
\hline Singapore & 539 & Turkey & 9 & Ukraine & 3 \\
\hline India & 189 & Cyprus & 7 & Estonia & 3 \\
\hline Israel & 93 & $\begin{array}{c}\text { The united Arab } \\
\text { emirates }\end{array}$ & 8 & Sri Lanka & 2 \\
\hline Russia & 90 & Lebanon & 5 & Jordan & 1 \\
\hline Malaysia & 77 & Greece & 8 & Pakistan & 1 \\
\hline Philippines & 32 & Egypt & 6 & Bangladesh & 1 \\
\hline Thailand & 25 & Qatar & 5 & Georgia & 1 \\
\hline Poland & 28 & Vietnam & 5 & Slovenia & 1 \\
\hline Czech republic & 29 & Slovakia & 5 & Croatia & 1 \\
\hline Hungary & 12 & Romania & 4 & Bulgaria & 1 \\
\hline Indonesia & 9 & Cambodia & 4 & & \\
\hline
\end{tabular}

Figure 2. Regional distribution of cooperative patents.

Table 1. Number distribution of cooperative patents. 
Table 2. "One Belt and One Road" regional division.

\begin{tabular}{|c|c|}
\hline Regional division & Nation \\
\hline North Asia (2 countries) & Mongolia, Russia \\
\hline Central Asia ( 5 countries) & Kazakhstan, Uzbekistan, Turkmenistan, Tajikistan, Kyrgyzstan \\
\hline $\begin{array}{l}\text { Southeast Asian } \\
\text { (11countries) }\end{array}$ & $\begin{array}{l}\text { Singapore, Malaysia, Indonesia, Myanmar, Thailand, Laos, Cambodia, } \\
\text { Vietnam, Brunei, Philippines, East Timor }\end{array}$ \\
\hline South Asia (8 countries) & $\begin{array}{l}\text { India, Pakistan, Bangladesh, Afghanistan, Sri Lanka, Maldives, Nepal } \\
\text { and Bhutan }\end{array}$ \\
\hline $\begin{array}{l}\text { Central and Eastern } \\
\text { European ( } 19 \text { countries) }\end{array}$ & $\begin{array}{l}\text { Poland, Lithuania, Estonia, Latvia, Czech republic, Slovakia, Hungary, } \\
\text { Slovenia, Croatia, Bosnia and Herzegovina, Montenegro, Cyprus, } \\
\text { Albania, Romania, Bulgaria, Macedonia, Ukraine, Belarus, Moldova }\end{array}$ \\
\hline $\begin{array}{l}\text { West Asia, the Middle East } \\
\text { ( } 20 \text { countries) }\end{array}$ & $\begin{array}{l}\text { Iran, Iraq, Turkey, Syria, Jordan, Lebanon, Israel, Palestine, Saudi } \\
\text { Arabia, Yemen, Oman, Uae, Qatar, Kuwait, Bahrain, Greece, Georgia, } \\
\text { Azerbaijan, Egypt, Armenia }\end{array}$ \\
\hline
\end{tabular}

\subsection{Cooperative Patent Applicant}

Before by analyzing the cooperative patent applicants from China and countries along the "One Belt and One Road" route in USPTO database, the applicants who had applied for more than 10 applicants are shown in Table 3. As can be seen from the above list, there are 16 enterprises or organizations have applied for more than 10 cooperative patents, among which 13 are dominated by multinational enterprises, especially the multinational technology companies in American. In terms of international applications, Huawei Technologies Corporation (51), International Business Machines Corporation (44) and General Electric Company (37) were the top three organizations.

\subsection{Cooperative Patent Application Field}

The cooperative patent IPC number will be used as a classification standard to conduct statistics on the cooperation patents between China and the "One Belt and One Road". Therefore, based on the USPTO database, the application field of international patents is analyzed, as shown in Table 4. It can be seen from Table 4 that the patent cooperation between China and the countries along the "One Belt and One Road" mainly focuses on the fields of electrical digital data processing, semiconductor devices, and wireless communication networks. Among them, Singapore, India, Russia and Israel are the major cooperation countries in these fields.

\section{Sample Selection}

\subsection{Model Setting}

Based on the method of Zhang Cui and Ouyang dongping (2017), this paper introduces the gravity model into the international scientific research cooperation [23]. It combines the current situation of scientific research cooperation, and builds a new gravity model suitable for the study of international scientific research cooperation on the basis of the original gravity model. The mathematical expression equation of the known gravity model is: 
Table 3. Distribution of applicants from countries along the "One Belt and One Road" in China.

\begin{tabular}{cccc}
\hline Applicant & $\begin{array}{c}\text { Application } \\
\text { Number }\end{array}$ & Type & Country/Region \\
\hline Huawei Technologies Co., Ltd. & 51 & Company & China \\
International Business Machines Corporation & 44 & Company & America \\
General Electric Company & 37 & Company & America \\
GEM Service, Inc Santa Clara Ca & 35 & Company & America \\
Microsoft Corporation & 33 & Company & America \\
Honeywell International, Inc. & 23 & Company & America \\
Nokia Technologies Oy & 22 & Company & Finland \\
Basf SE Ludwigshafen N/A DE & 22 & Company & Germany \\
Chartered Semiconductor Manufacting & 19 & Company & Singapore \\
Freescale Semiconductor, Inc. & 19 & Company & America \\
Futurewei Technologies, Inc. & 18 & Company & America \\
Schlumberger Technology Corporation & 15 & Company & America \\
Stats Chip PAC Pte. Ltd. & 15 & Company & Singapore \\
National University of Singapore SG & 13 & University & Singapore \\
City University of HONG KONG & 11 & University & Hongkong \\
Nanyang Technological University & 11 & University & Singapore \\
\hline
\end{tabular}

Table 4. Main application areas of China's cooperation with the "One Belt and One Road" countries.

\begin{tabular}{lll}
\hline IPC & Code Definition & Major partner countries in the technical field \\
\hline G06F & Electrical digital data processing & India (88), Singapore (70), Israel (54) \\
H01L & Semiconductor device & Singapore (97), Malaysia (24), Philippines (9) \\
H04W & Wireless communication network & Russia (73), Singapore (57), Israel (17) \\
H04L & Transmission of digital information & Singapore (68), Russia (60), India (38) \\
A61K & Medical and other preparations & Singapore (44), India (18), Thailand (8) \\
H04B & Transmission & Singapore (25), Russia (29), India (3) \\
H04N & Image communication & Singapore (20), Russia (5), India (3) \\
C07D & Heterocyclic compound & Israel (18), Singapore (9), India (5) \\
G06Q & Data processing system or method & India (14), Israel (5), Singapore (3) \\
G01N & Testing or analyzing materials & Singapore (8), India (4), Russia (3) \\
\hline
\end{tabular}

$$
F_{i, j}=A_{i} B_{j} C\left(d_{i, j}\right)
$$

In the equation, $F_{i, j}$ represents the relationship between $i$ and $j, A_{i}$ and $B_{j}$ represents the respective masses of two objects, and $C\left(d_{i, j}\right)$ represents other factors affecting the interaction between $A_{i}$ and $B_{j}$. 
In order to facilitate the cooperation of patents between China and the countries along the "One Belt and One Road", an empirical study on the factors affecting international patent cooperation is taken. This paper further refines the most general form of the gravity model and obtains the following mathematical expression:

$$
F_{i, j, t}=\alpha_{0}+\alpha_{1} p_{i, t}^{\lambda_{1}} p_{j, t}^{\lambda_{2}}\left[\sum_{K=1}^{K} e_{k} d_{i, j}^{K}\right]+\beta_{i, j, t}
$$

where, $F_{i, j, t}$ represents the relationship between object $i$ and object $j$ in time $t$, $p_{i, t}$ represents the scientific research strength of $i$ in $t$ year, $p_{j, t}$ represents the scientific research accumulation of $j$ country in $t$ year, $\alpha_{0}, \alpha_{1}$ represents the influence coefficient, $d_{i, j}^{K}$ represents the value of the influence factor $K, e_{k}$ represents the coefficient of $d_{i, j}^{K}$.

Next, the article brings in the explained variables and core explanatory variables, you can get:

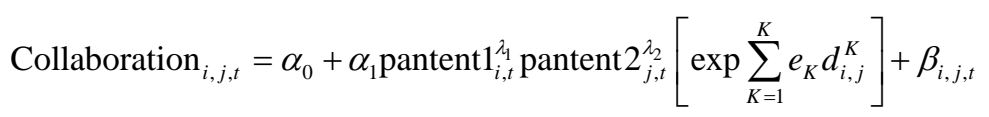

Collaboration $_{i, j, t}$ refers to the number of cooperative patents between China $i$ and the countries $j$ along the "One Belt and One Road" in $t$ year, pantent $1_{i, t}$ referring to the number of patents in China in $t$ year, pantent $2_{j, t}$ referring to the number of patents in the countries along the "One Belt and One Road" in $t$ year.

Finally, the control variables are brought into this paper, and the practice of Shi chaoxing and Guhaiying (2005) and Zhang haiwei (2010) is used for reference to carry out derivation and obtain [24] [25]:

Collaboration $_{i, j, t}=\alpha_{0}+\alpha_{1}$ Inpantent $_{i, t}+\alpha_{2}$ Inpantent $_{j, t}+\left[\exp \sum_{K=1}^{K} e_{K} d_{i, j}^{K}\right]+\beta_{i, j, t}(4)$

\subsection{Sample Selection}

- Explained Variables

This paper selects the number of cooperative patents between China and the "One Belt and One Road" countries in 2008-2017 as the explanatory variables. In terms of data acquisition, referring to Liu Yun's (2012) point of view, the United States Patent and Trademark Office (USPTO) database defines as long as the inventor's nationality includes the cooperation patents of China and the countries along the "One Belt and One Road" as international cooperation patents. And it does not distinguish whether there are inventors from other countries in the inventor [26].

- Core Explanatory Variables

China's scientific research strength (patent 1): the number of patents of China in each year from 2008 to 2017 is selected as the data of scientific research strength.

Scientific research strength of countries along the "One Belt and One Road" route (patent 2): the number of patents of countries along the "One Belt and 
One Road" route from 2008 to 2017 is selected as the data of scientific research strength.

Geographic distance (gd): Schwens C (2011) shows that the most common statistical method used in geography is to use Google Maps or other means of measurement to calculate the linear distance between the capitals or the distance of the aircraft [27]. However, such a method has its obvious drawbacks and is easily handled as a fixed effect when it is used for gravitational model measurement. But it cannot be recognized by software, so it has been gradually abandoned. This paper uses the measurement method of Jiang Guanhong (2012): the geographical distance is equal to the bilateral distance multiplied by the international oil price [28]. The geographic distance data comes from the CEPII database, and the international oil price comes from the US Energy Information Administration (EIA) database. And the international oil price used here is the weighted international oil price.

- Control Variables

Innovative capability (in): Existing research shows that innovation is an important factor affecting the development of national science and technology. The stronger the innovation capability, the greater the number of international cooperation patents in emerging technology fields and the higher the quality. The article here refers to the Innovation Indicators in the Global Competitiveness Index Report as a measure of the innovation capabilities of China and the countries along the "One Belt and One Road".

Bilateral relationship (re): when measuring the relationship between two countries, this paper classifies and assigns the value of bilateral partnership. This article, by consulting the official website of the Ministry of Foreign Affairs of the People's Republic of China, finds the bilateral relationship between China and the countries along the "One Belt and One Road" and classifies the bilateral relations according to the closeness of the country. It is divided into: general partnerships, strategic partnerships, and comprehensive strategic partnerships with assignments of 0,1 , and 2, respectively.

Economic scale (gdp): DuanQingfeng (2018) shows that capital has a direct impact on patent cooperation that the larger the economy of a country, the closer the patent cooperation [29]. In this paper, when measuring the size of a country's economy, this paper uses the indicator of gross national product, which is derived from the gross national product of the countries along the "One Belt and One Road" based on the 2010 constant US dollar disclosed by the The World Bank. To prevent data from being too large, this article records the unit of data as $\$ 100$ billion.

- Virtual Variables

Neighboring countries (tig): In measuring the geographical location of China along with the "One Belt and One Road" countries, this paper has added a measure of whether there is border bordering. This article regards whether China and the countries along the "One Belt and One Road" have borders as a virtual variable. If two countries border on each other, it's one; otherwise, it's zero. 
Language (lan): this paper also introduces common language as dummy variable. If there is a common language, it is denoted as 1 ; otherwise, it is denoted as 0 .

The specific explanatory variables and data related information are shown in Table 5:

- Sample Selection

Up to now, the number of countries along the "One Belt and One Road" has reached 65. This paper selects its data from 2008-2017 for a total of ten years for analysis. However, due to wars and inconsistent statistical methods, there is a lack of relevant variable data. Finally, this article deducts the countries along the "One Belt and One Road" that cannot obtain data information, and finally selects 45 countries along the "One Belt and One Road" as samples. Descriptive statistical analysis of each variable is shown in Table 6 and the specific sample countries and regions can be seen in the footnotes ${ }^{1}$.

\section{Empirical Analysis}

In this paper, using the 14th edition stata software, the panel data model is used to establish the gravity model. Then through the Huasman test to determine the model should use the time trend fixed effect model, and the specific test results are shown in Table 7. Since the number of collaborative papers in the interpretative variable is a non-negative integer measure and there is a zero value, a negative binomial fixed-effects regression model is used. Besides, considering that there may be endogeneity between the interpreted and explanatory variables, this paper refers to the existing literature (Zhao Wei and Zhang Cui (2007); KeShanxue and Zhao Wei (2014)), all explanatory variables are Laid the first phase of treatment [30] [31]. Next, we will use the negative binomial fixed effect model to conduct full sample test and time-separated test.

\subsection{Full Sample Regression}

This sample regression test first regresses the core variables, and then continuously adds new control variables to the original ones, and then obtains the final empirical results. Table 8 is the full sample regression results:

The variable Lnpatent1, the data passed the $1 \%$ significance level, and the coefficient is positive, indicating that China's scientific research strength has a significant positive correlation with the number of patents between China and the countries along the "One Belt and One Road". Moreover, the Lnpatent1 coefficient is larger than 0.7 , indicating that the number of Chinese scientific research patents changes by one unit, and the number of international cooperation patents changes by more than 0.7 units. From that, it can be seen the number of

${ }^{1}$ Sample countries: Mongolia, Russia, Kazakhstan, Singapore, Malaysia, Indonesia, Thailand, Cambodia, Vietnam, Brunei, the Philippines, India, Pakistan, Bangladesh, Sri Lanka, Nepal, Bhutan, Poland, Lithuania, Estonia, Latvia, Croatia, the Czech republic, Hungary, Slovenia, Bulgaria, Albania, Macedonia, Ukraine, Iran, Turkey, Jordan, Israel, Saudi Arabia, Oman, the United Arab emirates, Qatar, Kuwait, bahrain, Greece, Cyprus, Egypt, Georgia, Azerbaijan, Armenia. 
Table 5. Data sources and descriptions of variables.

\begin{tabular}{|c|c|c|c|c|}
\hline Variable & & Measurement index & Data sources & $\begin{array}{l}\text { Expected } \\
\text { benefits }\end{array}$ \\
\hline \multirow{3}{*}{$\begin{array}{l}\text { Core } \\
\text { explanatory } \\
\text { variables }\end{array}$} & $\begin{array}{l}\text { China's scientific } \\
\text { research strength }\end{array}$ & $\begin{array}{l}\text { Number of patents in } \\
\text { China from } 2008 \text { to } 2017\end{array}$ & $\begin{array}{l}\text { The USPTO } \\
\text { Database }\end{array}$ & $\begin{array}{l}\text { Positive } \\
\text { Correlation }\end{array}$ \\
\hline & $\begin{array}{l}\text { Scientific research } \\
\text { strength of countries } \\
\text { along the "One Belt } \\
\text { and One Road" } \\
\text { route }\end{array}$ & $\begin{array}{l}\text { Number of patents in } \\
\text { countries along "One Belt } \\
\text { and One Road" from } 2008 \\
\text { to } 2017\end{array}$ & $\begin{array}{l}\text { The USPTO } \\
\text { Database }\end{array}$ & $\begin{array}{l}\text { Positive } \\
\text { Correlation }\end{array}$ \\
\hline & $\begin{array}{l}\text { Geographic } \\
\text { distance }\end{array}$ & $\begin{array}{l}\text { Bilateral distance multiplied } \\
\text { by the weight of the } \\
\text { international oil price }\end{array}$ & $\begin{array}{l}\text { The CEPII } \\
\text { Database } \\
\text { EIA Database }\end{array}$ & $\begin{array}{l}\text { Negative } \\
\text { Correlation }\end{array}$ \\
\hline \multirow{3}{*}{$\begin{array}{l}\text { Control } \\
\text { variables }\end{array}$} & $\begin{array}{l}\text { Innovative } \\
\text { capability }\end{array}$ & $\begin{array}{l}\text { The innovation capability } \\
\text { index in the "Global } \\
\text { Competitiveness Index Report" }\end{array}$ & $\begin{array}{l}\text { "Global } \\
\text { Competitiveness } \\
\text { Index Report" }\end{array}$ & $\begin{array}{l}\text { Positive } \\
\text { Correlation }\end{array}$ \\
\hline & $\begin{array}{l}\text { Bilateral } \\
\text { relationship }\end{array}$ & $\begin{array}{l}\text { Valuation of bilateral relations } \\
\text { between the two countries }\end{array}$ & $\begin{array}{l}\text { Official website } \\
\text { of the Ministry of } \\
\text { Foreign Affairs }\end{array}$ & $\begin{array}{l}\text { Positive } \\
\text { Correlation }\end{array}$ \\
\hline & Economic scale & $\begin{array}{l}\text { Gross national product of } \\
\text { countries along the "One Belt } \\
\text { and One Road" route }\end{array}$ & The World Bank & $\begin{array}{l}\text { Positive } \\
\text { Correlation }\end{array}$ \\
\hline \multirow{2}{*}{$\begin{array}{l}\text { Virtual } \\
\text { variables }\end{array}$} & $\begin{array}{l}\text { Neighboring } \\
\text { countries }\end{array}$ & Whether have borders? & $\begin{array}{l}\text { The CEPII } \\
\text { Database }\end{array}$ & $\begin{array}{l}\text { Positive } \\
\text { Correlation }\end{array}$ \\
\hline & Language & $\begin{array}{l}\text { Whether the language } \\
\text { the same? }\end{array}$ & $\begin{array}{l}\text { The CEPII } \\
\text { Database }\end{array}$ & $\begin{array}{l}\text { Positive } \\
\text { Correlation }\end{array}$ \\
\hline
\end{tabular}

Table 6. Statistical description of each variable.

\begin{tabular}{cccc}
\hline Variable & Observation data & Maximum value & Minimum value \\
\hline Collaboration & 450 & 88 & 0 \\
Lnpatent1 & 450 & 9.803 & 8.087 \\
Lnpatent2 & 450 & 7.301 & 0 \\
lngd & 450 & 13.950 & 10.834 \\
in & 450 & 5.53 & 2.67 \\
gdp & 450 & 26.290 & 0.068 \\
re & 450 & 2 & 0 \\
tig & 450 & 1 & 0 \\
\hline
\end{tabular}

Table 7. Hausman test of factors affecting scientific research cooperation between China and the "One Belt and One Road" countries.

\begin{tabular}{ccc}
\hline Name & \multicolumn{2}{c}{ Variables and values } \\
\hline Testing method & Numerical value & Probability value \\
Huasman Test & 20.86 & 0.002 \\
\hline
\end{tabular}


Table 8. Full sample regression results.

\begin{tabular}{|c|c|c|c|c|c|c|}
\hline & (1) & (2) & (3) & (4) & (5) & (6) \\
\hline Lnpatent1 & $\begin{array}{c}1.023^{* * *} \\
(0.150)\end{array}$ & $\begin{array}{c}0.910^{\star * *} \\
(0.150)\end{array}$ & $\begin{array}{c}0.880^{* * *} \\
(0.151)\end{array}$ & $\begin{array}{c}0.783^{\star * *} \\
(0.157)\end{array}$ & $\begin{array}{c}0.723^{\star * *} \\
(0.160)\end{array}$ & $\begin{array}{c}0.718^{\star * *} \\
(0.145)\end{array}$ \\
\hline Lnpatent2 & $\begin{array}{c}0.206^{* * *} \\
(0.116)\end{array}$ & $\begin{array}{c}0.265^{\star * *} \\
(0.120)\end{array}$ & $\begin{array}{c}0.217^{\star * *} \\
(0.116)\end{array}$ & $\begin{array}{c}0.244^{\star * *} \\
(0.096)\end{array}$ & $\begin{array}{c}0.255^{\star * *} \\
(0.100)\end{array}$ & $\begin{array}{c}0.203^{\star * *} \\
(0.110)\end{array}$ \\
\hline lngd & $\begin{array}{l}-0.176 \\
(0.199)\end{array}$ & $\begin{array}{l}-0.110 \\
(0.200)\end{array}$ & $\begin{array}{l}-0.109 \\
(0.960)\end{array}$ & $\begin{array}{l}-0.110 \\
(0.186)\end{array}$ & $\begin{array}{l}-0.110 \\
(0.188)\end{array}$ & $\begin{array}{l}-0.157 \\
(0.174)\end{array}$ \\
\hline in & & $\begin{array}{l}0.568^{\star *} \\
(0.257)\end{array}$ & $\begin{array}{l}0.639^{\star *} \\
(0.256)\end{array}$ & $\begin{array}{c}0.670^{\star * *} \\
(0.258)\end{array}$ & $\begin{array}{l}0.634^{\star *} \\
(0.283)\end{array}$ & $\begin{array}{l}0.427^{\star *} \\
(0.290)\end{array}$ \\
\hline re & & & $\begin{array}{l}0.343^{\star} \\
(0.190)\end{array}$ & $\begin{array}{l}0.345^{\star} \\
(0.178)\end{array}$ & $\begin{array}{l}0.402^{\star *} \\
(0.203)\end{array}$ & $\begin{array}{l}0.437^{\star *} \\
(0.120)\end{array}$ \\
\hline gdp & & & & $\begin{array}{c}0.056^{\star * *} \\
(0.281)\end{array}$ & $\begin{array}{c}0.068^{\star * *} \\
(0.293)\end{array}$ & $\begin{array}{c}0.080^{\star * *} \\
(0.319)\end{array}$ \\
\hline tig & & & & & $\begin{array}{c}-1.114^{*} \\
(0.862)\end{array}$ & $\begin{array}{c}-1.580^{*} \\
(0.945)\end{array}$ \\
\hline lan & & & & & & $\begin{array}{l}1.613^{*} \\
(0.961)\end{array}$ \\
\hline constant & $\begin{array}{c}-6.218^{*} \\
(3.617)\end{array}$ & $\begin{array}{c}-8.985^{\star *} \\
(3.693)\end{array}$ & $\begin{array}{c}-8.920^{* *} \\
(3.714)\end{array}$ & $\begin{array}{c}-8.688^{\star *} \\
(3.943)\end{array}$ & $\begin{array}{c}-7.663^{\star *} \\
(4.025)\end{array}$ & $\begin{array}{c}-6.167^{\star *} \\
(3.825)\end{array}$ \\
\hline observations & 450 & 450 & 450 & 450 & 450 & 450 \\
\hline
\end{tabular}

Note: ${ }^{* *},{ }^{* *}, *$, respectively, are significant at the level of $1 \%, 5 \%$, and $10 \%$, and the standard deviation of robustness in parentheses.

Chinese scientific research patents is the core factor affecting China's patent cooperation with countries along the "One Belt and One Road". But as the number of control variables continues to decrease, it shows that there may be more potential factors that affect China's patent cooperation with the "One Belt and One Road" countries, which lead the impact of Chinese scientific research capabilities on him is constantly decreasing. Variable Lnpatent2 shows a relatively high level of data significance. All of them pass the significance level of $1 \%$ and the coefficient is positive and relatively stable, indicating that the scientific research strength of countries along the "One Belt and One Road" route plays a role in promoting China's patent cooperation with it. In general, the variable lngd does not pass the significance level test at the degree of $10 \%$ and does not conform to the original hypothesis effect. The possible explanation is that the national patent cooperation is different from other scientific research cooperation projects. It has the characteristics of being more convenient and easy to operate. The emergence of new communication methods such as network, mail and video can greatly reduce the distance constraints.

As for other control variables and virtual variables, we can see that innovation ability, economic scale have a significant impact on China and the "One Belt and One Road" countries, and they all play a positive role in promoting national patent cooperation. Besides, They passed the significance test on the basis of 5\% 
and $1 \%$, respectively. One the other hand, the bilateral relations, language and bordering between countries have an impact on international patent cooperation, but the impact is small that they only pass the significant at $10 \%$ degree. The border between the two countries shows that it has a hindrance to national patent cooperation at $10 \%$ significant. The possible reason is that the countries bordering China are mostly developing countries, and their scientific research strength is weak, and scientific research is not open.

From the regression results, the data is generally significant, especially most of the core variables have passed the high significance test. From the value of empirical results, except the national borders will hinder the development of international patent activities; the scientific research, innovation, bilateral relations, economic scale and common language of China and other countries along the "One Belt and One Road" have played a positive role in promoting international patent cooperation. And the strength of Chinese scientific research is a key factor in promoting patent cooperation between China and countries along the "One Belt and One Road".

\subsection{Time Period Regression}

In order to better analyse the changes in the factors affecting scientific research cooperation between China and countries along the "One Belt and One Road" before and after the implementation of the "One Belt and One Road" Strategy, we are now carrying out time segmentation and time-specific regression tests. Data for 2008-2017 are divided into two phases: the pre-"One Belt and One Road" strategy (2008-2012) and the post-"One Belt and One Road" strategy (2013-2017). And because virtual variables have less influence on patent cooperation, only control variables are introduced in the later regression. Table 9 is the result of time-limited regression:

The pre-“One Belt and One Road" Strategy (2008-2012): China and countries along the "One Belt and One Road" continue to have an important influence on international patent cooperation at $1 \%$ significant. However, the innovation power of one country, bilateral relations between the two countries, and the size of the country's economy have no significant impact on international patent cooperation, because they don't pass the significant test. It is speculated that the reason is that most of the "One Belt and One Road" countries are developing countries, and their scientific research strength is weak and their economic base is poor so that their enthusiasm for cooperative scientific research in the early days was not high. The post-“One Belt and One Road” Strategy (2013-2017): With the continued investment in scientific research and innovation between China and countries along the "One Belt and One Road", innovation has become another important factor that has affected scientific research cooperation between countries after the strength of national scientific research at $1 \%$ significant test. However, geographical distance, bilateral relations between the two countries, and the country's economic size variables do not pass the significant test and had nothing to do with international patent cooperation. 
Table 9. Time-lapse regression results.

\begin{tabular}{ccc}
\hline & $2008-2012$ & $2013-2017$ \\
\hline Lnpatent1 & $1.396^{* * *}$ & $1.048^{* * *}$ \\
& $(0.742)$ & $(0.315)$ \\
Lnpatent2 & $0.309^{* * *}$ & $0.315^{* * *}$ \\
& $(0.662)$ & $(0.125)$ \\
lngd & -0.317 & -0.206 \\
& $(0.258)$ & $(0.235)$ \\
in & -1.799 & $1.163^{* * *}$ \\
& $(0.753)$ & $(0.364)$ \\
re & 0.405 & -0.680 \\
& $(0.455)$ & $(0.287)$ \\
gdp & 0.0304 & 0.046 \\
& $(0.229)$ & $(4.570)$ \\
constant & 16.007 & $-16.828^{* * *}$ \\
& $(24.564)$ & $(5.999)$ \\
observations & 225 & 225 \\
\hline
\end{tabular}

Figures and Tables Note: ${ }^{* * *},{ }^{* *},{ }^{*}$, respectively, are significant at the level of $1 \%, 5 \%$, and $10 \%$, and the standard deviation of robustness in parentheses.

Since the "One Belt and One Road" Strategy, the impact of China's scientific research on international patent cooperation has diminished. However, the strength of Chinese scientific research is still the core factor in promoting patent cooperation between China and countries along the "One Belt and One Road". And with the emphasis on scientific research innovation, innovation has become one of the driving factors that affect international scientific research cooperation.

\subsection{Robustness Test}

From a theoretical perspective, there may be missing variables in the model constructed in this paper, which makes the accuracy of the empirical results biased. Therefore, it is necessary to test the robustness of the model. The robustness test can generally be implemented by replacing the estimation method or the substitution variable. This paper will use the least squares method to test the robustness of the article, as shown in Table 10. From the test results, it can be found that the original conclusion has not changed substantially, which also indicates that the empirical analysis of the model is robust and reliable.

\section{Conclusions and Policy Recommendations}

This paper uses the data of national patent cooperation between China and the "One Belt and One Road" in the USPTO database from 2008 to 2017 to analyze the status quo of scientific cooperation between China and countries along the route. And it makes an empirical study on factors affecting patent cooperation between China and countries along the "One Belt and One Road" by means of 
Table 10. Robustness test.

\begin{tabular}{cc}
\hline Lnpatent1 & $1.987^{* * *}$ \\
& $(0.192)$ \\
Lnpatent2 & $0.387^{* * *}$ \\
& $(0.683)$ \\
lngd & -3.899 \\
& $(0.824)$ \\
in & $0.116^{* * *}$ \\
& $(0.413)$ \\
re & $0.407^{* * *}$ \\
& $(0.555)$ \\
gdp & $0.134^{* * *}$ \\
& $(0.238)$ \\
constant & $60.820^{* *}$ \\
observations & $(14.719)$ \\
\end{tabular}

Note: ${ }^{* *}, * *, *$, respectively, are significant at the level of $1 \%, 5 \%$, and $10 \%$, and the standard deviation of robustness in parentheses.

gravitational model. The study found that the total number of patents between China and the countries along the "One Belt and One Road" has been increasing year by year, but its cooperation is not high and its distribution is uneven. The current situation shows that the top five countries in the cooperation have concentrated $80.937 \%$ of the total number of patents, but there are still 31 countries along the "One Belt and One Road" that have not cooperated with China. Besides, in terms of regional distribution: the cooperative countries are mainly concentrated in South Asia and Southeast Asia, while there are no cooperative patents in West Asia and China. As for the influencing factors, in addition to the bordering of countries, it will hinder international patent activities. The scientific research strength, national innovation capability, bilateral relations, economic scale and common language of China and the countries along the "One Belt and One Road" Initiative will promote the important factors of transnational patent cooperation among countries. The geographical distance between the two countries has no significant impact on national patent cooperation.

Based on the above conclusions, this paper draws the following enlightenment:

First, China should increase investment in scientific research, improve scientific research efficiency and technological innovation capabilities, and enhance its scientific research capabilities. In addition, China should raise the intellectual property protection system to the height of the national strategy and promote the revision of the new edition of the Intellectual Property Law of the People's Republic of China as soon as possible to provide a good institutional environment for scientific research and innovation. At the same time, the government should increase financial support for scientific research and formulate a reason- 
able incentive system for scientific research results. For example, the government should encourage researchers to publish world-class scientific papers and high-level invention patents, and promote scientific research to a world-class country. Besides, it is necessary to reform the compensation system for scientific research personnel, increase the proportion of basic wages, and reduce their dependence on project funding. This can improve the actual income and social status of researchers and enhance the enthusiasm of researchers. In education, the government should strengthen investment in education, reform the existing education system, and promote quality education and individuality education. For example, on the one hand, the government should attach importance to innovation and practice education, liberate students' thinking. On the other hand, government should improve students' competitiveness and cultivate world-class talents with innovative spirit and creative ability.

Second, China should strengthen its political, economic, and cultural ties with countries along the "One Belt and One Road" to lay a good foundation for promoting scientific research cooperation between China and the countries along the "One Belt and One Road". For example, China should further expand its foreign investment and import and export trade to countries along the "One Belt and One Road" by strengthening China's economic cooperation with countries along the "One Belt and One Road". In addition, China can promote scientific research cooperation through economic cooperation, and promote Chinese multinational enterprises to carry out patent cooperation with countries along the "One Belt and One Road".

Third, the uneven distribution of scientific research cooperation areas between China and the "One Belt and One Road" countries requires a new situation of scientific research cooperation between China and the "One Belt and One Road" marginalized countries. Therefore, China needs to further deepen its patent cooperation with its superior partners and consolidate the achievements of existing scientific and technological cooperation. China can set up research institutes and other international research conferences by holding research institutes and other research institutes in the "One Belt and One Road" countries to promote international academic resources, science and technology, professional talents mobility and complementarity. It will have a great help for the "One Belt and One Road" countries to participate in the process of international patent cooperation.

\section{Conflicts of Interest}

The author declares no conflicts of interest regarding the publication of this paper.

\section{References}

[1] Michel, Z., Bassecoulard, E. and Okubo, Y. (2010) Shadows of the Past in International Cooperation: Collaboration Profiles of the Top Five Producers of Science. Scientometrics, 47, 627-657. https://doi.org/10.1023/A:1005632319799 
[2] He, T.-W. (2009) International Scientific Collaboration of China with the G7 Countries. Scientometrics, 80, 571-582. https://doi.org/10.1007/s11192-007-2043-y

[3] Wang, X.-W., Xu, S., Wang, Z., Peng, L. and Wang, C. (2013) International Scientific Collaboration of China: Collaborating Countries, Institutions and Individuals. Scientometrics, 95, 885-894. https://doi.org/10.1007/s11192-012-0877-4

[4] Bouabid, H., Larivière, V. and Paul-Hus, A. (2016) Scientific Collaboration and High-Technology Exchanges among BRICS and G-7 Countries. Sicentometrics, 106, 873-899. https://doi.org/10.1007/s11192-015-1806-0

[5] Finardi, U. and Buratti, A. (2016) Scientific Collaboration Framework of BRICS Countries: An Analysis of International Coauthorship. Sientometrics, 109, 433-446. https://doi.org/10.1007/s11192-016-1927-0

[6] Liu, Y. (2015) From the SCI Co-Authored Papers to See the Scientific Cooperation between the Five Countries of the BRICS. Global Technology and Economy Outlook, 30, 67-76.

[7] Sun, T. and Xu, C. (2015) Visualization Analysis of the "One Belt, One Road" Research Literature Based on CiteSpaceIII. Library and Information Service, 59, 135-137.

[8] Wu, J., Zheng, C. and Ji, Q. (2016) One Belt and One Road” Strategy Implementation and International Science and Technology Cooperation Innovation-Based on the Analysis of NSFC-Funded Papers. Intelligence Magazine, 33, 32-36.

[9] Zhou, J., Huang, Y., Wang, X., Chen, Y., Fu, W. and Ma, P. (2016) Research on the Situation of Scientific Research Cooperation between China and the "One Belt and One Road" Initiative-Based on the Measurement of Web of Science. Information Science, 4, 69-79.

[10] Ding, J.-L., Yang, L. and Sun, H. (2017) Research on the Scientific Research Cooperation Situation of the "One Belt and One Road" Region and Countries along the Route Based on Bibliometrics. Proceedings of the Chinese Academy of Sciences, 32, 626-636.

[11] Wang, J., Wang, R., Zeng, L., Zhao, Y. and Zhao, C. (2017) Evolution Analysis of National Scientific Research Cooperation Network along the "One Belt and One Road” from 1996 to 2015. Library and Information Service, 61, 76-83.

[12] Bi, L.-L., Lei, L. and Liu, W. (2018) National Patent Layout along the "One Belt and One Road” and China’s Patent Strategy. Global Economic Outlook, 33, 47-59.

[13] Ye, Y.-P., Ma, W.-C. and Zhang, G. (2016) Research on the Status Quo of Science and Technology Cooperation between China and the "One Belt and One Road" Countries-Based on Comparative Analysis of Patents and Papers. Document, Information and Knowledge, No. 4, 60-68.

[14] Sun, Q.-L. (2016) Analysis of Patent Distribution Patterns in Countries and Regions along the "One Belt and One Road" Initiative. Chinese Patents and Trademarks, No. 1, 13-17.

[15] Zhang, M.-Q. and Deng, M. (2016) Research on the Characteristics of Transnational Patent Cooperation between China and the Countries along the "One Belt and One Road”. Journal of Information, No. 4, 38-42.

[16] Zhang, M. and Ke, L. (2018) Research on the "One Belt, One Road" Multinational Patent Cooperation Network and Its Influencing Factors. Soft Science, 32, 21-25+29. https://doi.org/10.1007/978-3-319-92201-0_2

[17] Katz, J.S. (1994) Geographical Proximity and Scientific Collaboration. Scientometics, 31, 31-43. https://doi.org/10.1007/BF02018100

[18] Collins, H.M. (2001) Tacit Knowledge, Trust and the Q of Sapphire. Social Studies 
of Science, 31, 71-85. https://doi.org/10.1177/030631201031001004

[19] Adams, J.D., Black, G.C., Clemmons, J.R. and Stephan, P.E. (2005) Scientific Teams and Institutional Collaborations: Evidence from US Universities, 1981-1999. Research Policy, 34, 259-285. https://doi.org/10.1016/j.respol.2005.01.014

[20] Hoekman, J., Frenken, K. and Van Oort, F. (2009) The Geography of Collaborative Knowledge Production in Europe. The Annals of Regional Science, 43, 721-738. https://doi.org/10.1007/s00168-008-0252-9

[21] Wagner, C.S. and Leydesdorff, L. (2005) Network Structure, Self-Organization, and the Growth of International Collaboration in Science. Research Policy, 34, 1608-1618. https://doi.org/10.1016/j.respol.2005.08.002

[22] Han, T. and Tan, X. (2013) Measurement and Analysis of International Cooperation in Chinese Scientific Research. Science Research, 8, 1136-1140.

[23] Zhang, C. and Ouyang, D.-P. (2017) Research on the Influencing Factors of China's International Scientific Research Cooperation under the "One Belt, One Road" Strategy-An Empirical Analysis of Sino-Foreign Cooperation Scientific Research Papers Based on Web of Science Database. International Trade Issues, No. 4, 74-82.

[24] Shi, C. and Gu, H. (2005) New Progress in the Study of Trade Gravity Model and Its Application in China. Finance and Trade Research, No. 3, 27-32.

[25] Zhang, H. (2010) Overview of the Extension and Application of Trade Gravity Model. Commercial Economy, No. 2, 68-70.

[26] Liu, Y., Chen, Z.X. and Liu, W.L. (2012) Analysis and Policy Revelation on Patent Measurement for Sino-U.S. Cooperative Invention Authorization. Chinese Management Science, 20, 761-767.

[27] Schwens, C., Eiche, J. and Kabst, R. (2011) The Moderating Impact of Informal Institutional Distance and Formal Institutional Risk on SME Entry Mode Choice. Journal of Management Studies, 48, 330-351. https://doi.org/10.1111/j.1467-6486.2010.00970.x

[28] Jiang, G.-H. and Jiang, D.-C. (2012) Location Selection of China's Foreign Investment: Panel Data Inspection Based on Investment Gravity Model. World Economy, No. 9, 21-40.

[29] Duan, Q.-F. (2019) The Impact of Social Capital on the Binary Relationship of Patent Cooperation: The Regulating Effect of Absorptive Capacity and Protection Strength. Science and Technology Progress and Policy, 36, 11-17.

[30] Zhao, W. and Zhang, C. (2007) Regional Integration of FDI and China's Manufacturing Industry: An Empirical Analysis Based on 20 Industries. Economic Research, No. 11, 82-90.

[31] Ke, S.-X. and Zhao, W. (2014) Industrial Structure, City Scale and China's Urban Productivity. Economic Research, 49, 76-88. 